\title{
Thyroid Function and Obesity
}

\author{
Silvia Longhi, Giorgio Radetti \\ ${ }^{1}$ Regional Hospital of Bolzano, Department of Pediatrics, Bolzano, Italy
}

\begin{abstract}
Nowadays, childhood obesity is one of the biggest health emergencies in the developed countries. Obesity leads to multiple metabolic alterations which increase the risk of developing diabetes and cardiovascular diseases. Thyroid function has been often described as altered in obese children, however, it is not clear whether the altered thyroid function is the cause or the consequence of fat excess. On the other hand, thyroid structure seems also to be affected. Nevertheless, both functional and structural alterations seem to improve after weight loss and therefore no treatment is needed.

Key words: Thyroid, obesity, ultrasound
\end{abstract}

Conflict of interest: None declared

Received: 25.09.2012

Accepted: 25.10.2012

\section{Introduction}

Nowadays, childhood obesity represents one of the biggest health emergencies in developed countries; in the last 20 years, a $45 \%$ increment in the incidence of childhood obesity was observed in the USA (1). In Italy, approximately $21.2 \%$ of the subjects in the age range 0-18 years are overweight (2). Obesity frequently persists beyond childhood, and it has been estimated that about $80 \%$ of obese children become obese adults (3).

Obesity leads to multiple metabolic disorders that increase the mortality and morbidity risk in adulthood $(4,5,6)$ and contributes in a significant way to the pathogenesis of diabetes mellitus and cardiovascular disease. Actually, many of the complications associated with obesity already exist during childhood and are specifically related to the presence of an insulin resistance (7). An early screening intended to diagnose the metabolic syndrome already in childhood would be very important, but unfortunately, criteria for this diagnosis have not been well established for children. Currently, different classifications are proposed in order to meet this diagnosis $(8,9,10)$, but it seems difficult to establish a uniform classification system applicable universally, since many features of obesity change by ethnic group and also with the age of the patient (11).

\section{Thyroid Function and Obesity}

Long before the definition of the metabolic syndrome, alterations in thyroid function were reported in obese patients. Body composition and thyroid hormones appear to be closely related since the latter is known to be involved in the regulation of basal metabolism and thermogenesis, playing an important role in lipid and glucose metabolism, food intake and fat oxidation $(12,13)$. In agreement with this knowledge, it is well known that

\section{Address for Correspondence}

Giorgio Radetti MD, Regional Hospital of Bolzano, Department of Pediatrics, via L. Boehler 5, 39100 Bolzano, Italy Phone: +3904719098651 E-mail: giorgio.radetti@asbz.it

O.Journal of Clinical Research in Pediatric Endocrinology, Published by Galenos Publishing. 
Longhi S et al.

Thyroid and Obesity

hypothyroidism causes a weight increase together with a decrease in basal metabolic rate and thermogenesis (14). Moreover, it has also been reported that there is an inverse correlation between free thyroxine (fT4) values and body mass index (BMI), even when fT4 values remain in the normal range (15). Lately, it has also been suggested that abnormalities in thyroid function may be secondary to weight excess. These changes, however, would still be functional, as suggested by their normalization after weight loss $(16,17,18)$.

In various studies on adult obese individuals, thyroid hormone and thyroid-stimulating hormone (TSH) concentrations have been described as normal, elevated or reduced, compared to a control group $(16,19,20,21,22,23,24)$. In obese children, the most common abnormality is hyperthyrotropinemia $(17,18,25,26)$, as can be seen in Figure 1 which depicts the TSH values in a group of children affected by simple obesity and in a control group.

The causes underlying these alterations are not known although several theories have been proposed. These include an increased deiodinase activity, as suggested by the increase in total triiodothyronine (T3) and free T3 (fT3) reported in some subjects (26). The reported high conversion rate of T4 to T3 in obese patients has been also interpreted as a defense mechanism, capable of counteracting the accumulation of fat by increasing the energy expenditure $(27,28)$, basal metabolic rate and the total energy expenditure, being in fact positively related to the levels of total T3 and fT3. Leptin, a hormone produced by adipocytes (29), also alters the activity of deiodinases, thus promoting the conversion of T4 to T3 (30).

Another mechanism claimed to explain the high values of T3 and fT3 has been related to the fact that the expressions of both $\mathrm{TSH}$ and thyroid hormones are reduced in adipocytes of obese subjects as compared to individuals of normal weight. This would prompt a decreased tissue responsiveness to circulating thyroid hormones and would also explain the consequent increased compensatory secretion of TSH and fT3 in an attempt to force the state of peripheral resistance (31).

Another potential cause of increased blood concentration of

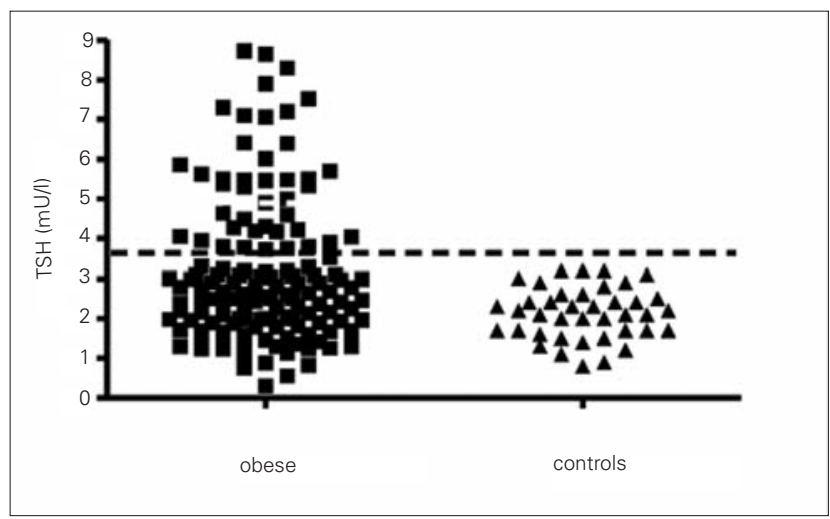

Figure 1. Thyroid-stimulating hormone (TSH) serum levels in a group of 143 obese children and in normal-weight children
TSH may be the high levels of leptin, found in obese subjects (25). The main action of leptin is to report centrally the amount of fat, leading to a decrease in appetite and food intake (32). In case of obesity, increased leptin is considered as an evidence of "leptin resistance" (32). In addition to this action, leptin has also been shown to stimulate centrally the transcription of pro thyrotropin-releasing hormone (TRH) and consequently also that of TRH and TSH (26). This increase in TSH, and therefore in T3, could be interpreted as a defense mechanism of the body against weight gain. In agreement with this interpretation, we observe the opposite in anorexia nervosa, in which low levels of fT3 and TSH (27) are interpreted as signs of a physiological adaptation to reduce metabolic energy expenditure (25). Moreover, TSH receptors are also localized in adipose tissue (33) and thus TSH may directly stimulate the production of leptin by adipocytes (34). Another explanation might be the impaired feedback due to a lowered number of T3 receptors in the hypothalamus (35).

A further explanation could be the inflammatory state that characterizes obesity. It is well recognized that in obesity, the adipose tissue secretes a distinct quantity of inflammatory cytokines, and some of these, such as tumor necrosis factor- $\alpha$, (TNF- $\alpha$ ) interleukin-1 (IL-1) and interleukin-6 (IL-6), escape into the general circulation provoking systemic symptoms (36). The secretion of these cytokines, which have been proven to inhibit sodium/iodide symporter (NIS) mRNA expression and iodide uptake activity in Fisher rat thyroid cell line (FRTL-5) and human thyroid cells $(37,38,39)$, might therefore explain the compensatory raised TSH level in obese individuals. This would also explain the tissue resistance to TSH and additionally its reversibility after weight loss.

Normalization of Thyroid Function After Weight Loss

Weight loss induces a significant decrease in serum fT3 and TSH levels $(16,17,18)$ (Figure 2). The decrease in thyroid hormones, which consequently also leads to a decrease in energy expenditure, would explain the difficulty to maintain the weight loss (40). Apart from weight reduction, it seems that

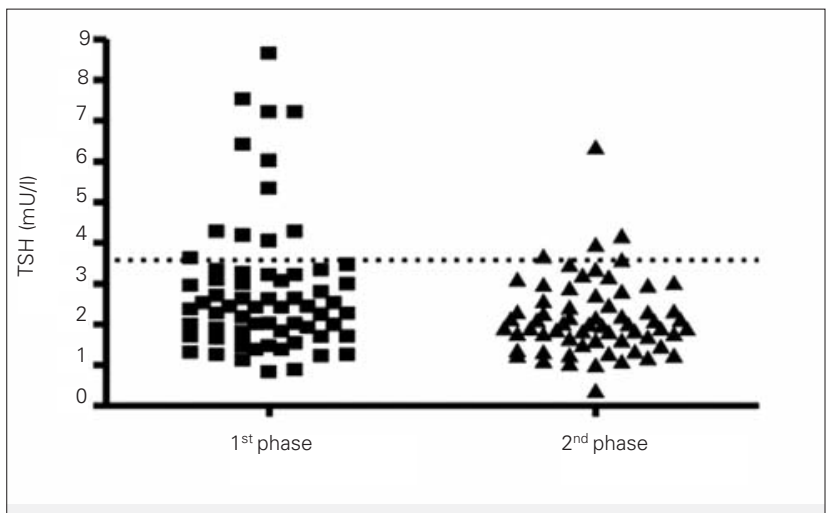

Figure 2. Thyroid-stimulating hormone (TSH) serum values before (1 1 st phase) and after weight loss (2nd phase) in a group of 72 obese children 
even simple changes of lifestyle, characterized by increased physical activity and improvement in body composition without concomitant changes of BMI, also lead to a decrease of TSH and fT3 (41). An explanation for these findings might be that weight loss or a modification in body composition reduces the state of inflammation which is present in these patients, leading to a decrease in the secretion of cytokines and therefore to a decreased inhibition on NIS and explaining therefore the improved function of the thyroid tissue (42).

\section{Thyroid Ultrasound Features in Obese Patients}

An association between obesity and increased thyroid volume has been reported in some studies, but recently, it has also been shown that obese pediatric patients frequently have an ultrasound pattern of the thyroid which is highly suggestive of Hashimoto's thyroiditis. These findings are not associated,
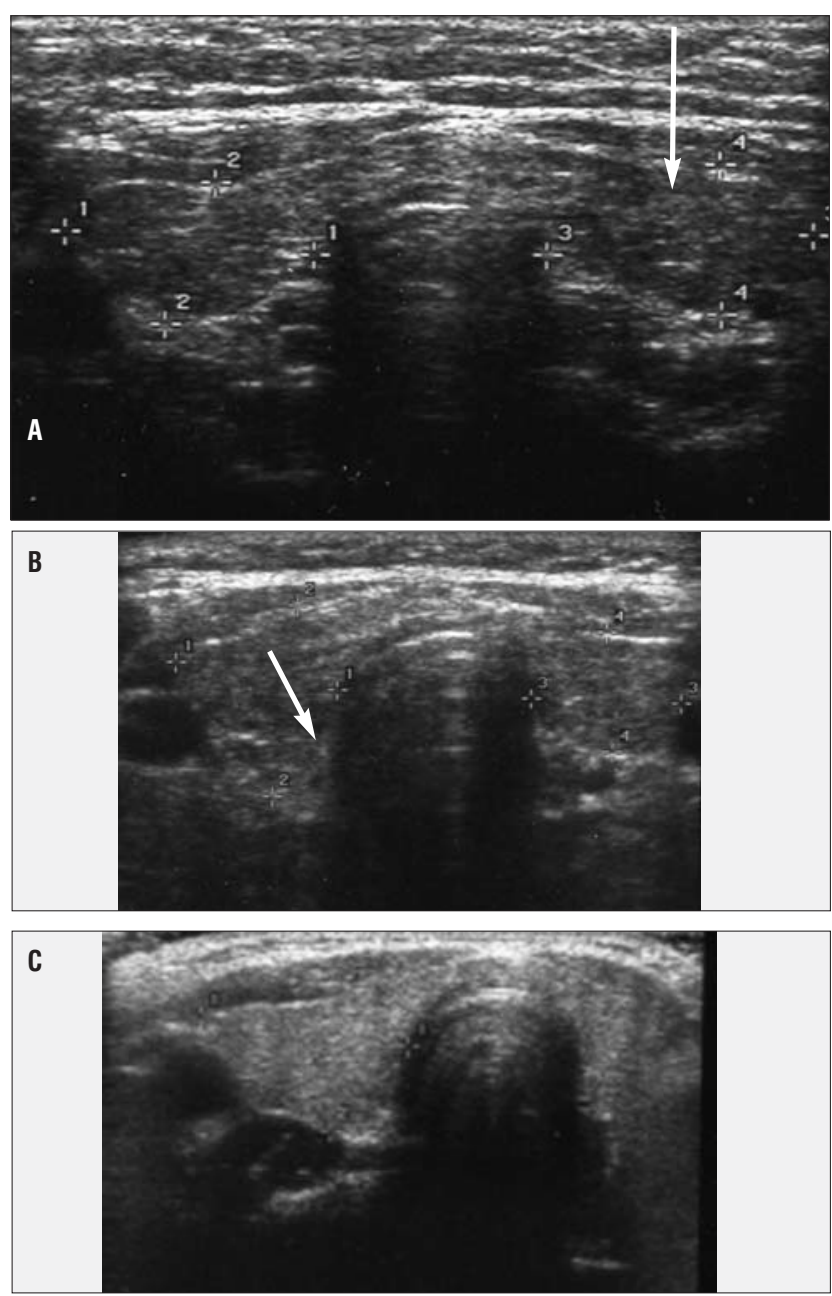

Figure 3. Thyroid ultrasound images in a subject with Hashimoto thyroiditis (A), in an obese child (B) and in a normal subject (C) however, with production of thyroid autoantibodies (Figure 3) (43). Similar observations have been reported also in an adult population of obese patients (44). The cause of these findings remains unknown. A thyroid fine-needle biopsy did not show any lymphocytic infiltrate, thus excluding a typical Hashimoto's thyroiditis. A possible but not proven cause might be, again, the low-grade inflammatory state that characterizes obesity (45). The adipose tissue in obese patients secretes inflammatory cytokines and some of these (such as TNF- $\alpha,|\mathrm{L}-1,| \mathrm{L}-6)$, entering the blood stream, can cause systemic symptoms (45). These cytokines, which contribute to increase the TSH, induce also vasodilation and increased permeability of blood vessels in the thyroid, thus causing plasma exudation and imbibition of the parenchyma; these changes may be responsible for the ultrasound findings. If this interpretation is correct, this would also explain why after weight loss and changes in lifestyle, there is a recovery of the structure of the thyroid gland (Figure 4) (41).

The state of fitness, in fact, and the reduction of the inflammatory state that follows the weight loss lead probably to the regression of parenchyma imbibition $(36,41,46)$.

On the other hand, a typical Hashimoto's thyroiditis may be present in obese children as well, and even with a higher frequency, but in most of these cases, thyroid autoantibodies are usually present (43).

In conclusion, obese children may show different degrees of alterations pertaining to thyroid function and therefore, caution is recommended when diagnosing Hashimoto's thyroiditis in these patients. The diagnosis should not be based just upon a pathological ultrasound, without establishing the presence of anti-thyroid antibodies. Regarding treatment, in agreement with others (18), we do not believe these children require any

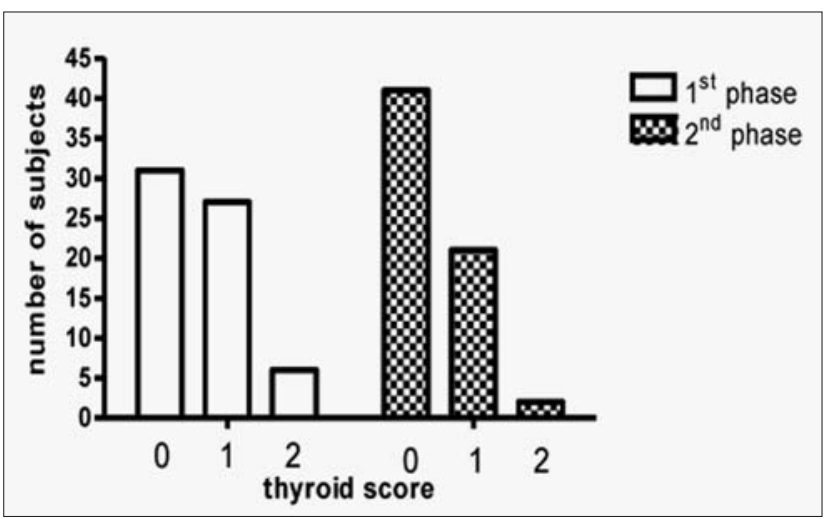

Figure 4. Thyroid score before (1st phase) and after weight loss (2nd phase)

The alterations of echogenicity and homogeneity of the parenchyma at ultrasound are quantified according to a pediatric scoring system. Score 0: normal; score 1: mild parcelled hypoechogenicity; score 2: severe parcelled hypoechogenicity; score 3: mild generalized hypoechogenicity; score 4: severe generalized hypoechogenicity; score 5: near-anechogenicity 
Longhi S et al.

Thyroid and Obesity

treatment, firstly, because the alterations found are only functional and revert to normal after weight loss or modifications in life style and secondly, because in all patients, despite a raised $\mathrm{TSH}$, normal or even elevated peripheral thyroid hormone levels have been reported in all studies. This condition does not fit with the definition of subclinical hypothyroidism, in which treatment might be considered.

\section{Acknowledgements}

We are indebted to Dr. Lucio Parmegiani for revising and correcting the manuscript.

\section{References}

1. Ogden CL, Carrol MD, Curtin LR, McDowell MA, Tabak CJ, Flegal KM. Prevalence of overweight and obesity in the United States, 1999-2004. JAMA 2006;295:1549-1555.

2. Caroli M, Pilot European Regional Interventions for Smart Childhood Obesity Prevention in Early Age 2009.

3. Serdula MK, Ivery D, Coates RJ, Freedmann DS, Williamson DF, Byers T. Do obese children become obese adults? A review of the literature. Prev Med 1993;22:167-177.

4. Daniels SR. The consequences of childhood overweight and obesity. Future Child 2006;16:47-67.

5. Weiss R, Dziura J, Burgert TS, Tamborlane WV, Taksali SE, Yeckel CW, Allen K, Lopes M, Savoye M, Morrison J, Sherwin RS, Caprio S. Obesity and the metabolic syndrome in children and adolescents. N Engl J Med 2004;350:2362-2374.

6. Pearce EN. Thyroid hormone and obesity. Curr Opin Endocrinol Diabetes Obes 2012;19:408-413.

7. Cali AM, Caprio S. Obesity in Children and Adolescents. J Clin Endocrinol Metab 2008;93:31-36.

8. Zimmet $P$, Alberti G, Kaufman F, Tajima N, Silink M, Arslanian $S$, Wong G, Bennett P, Shaw J, Caprio S. International Diabetes Federation Task Force on Epidemiology and Prevention of Diabetes. The metabolic syndrome in children and adolescents. Lancet 2007;369:2059-2061.

9. Caprio S. Definitions and pathophysiology of the metabolic syndrome in obese children and adolescents. Int $\mathrm{J}$ Obes (Lond) 2005;29:24-25.

10. Tailor AM, Peeters PH, Norat T, Vineis P, Romaguera D. An update on the prevalence of the metabolic syndrome in children and adolescents. Int J Pediatr Obes 2010;5:202-213.

11. Widhalm K. Metabolic syndrome in children: an imperative necessity for a unified definition. Eur J Clin Invest 2010;40:10611062. Epub 2010 Oct 8

12. Silva JE. Thermogenic mechanism and their hormonal regulation. Physiol Rev 2006:86:435-464.

13. Rosenbaum M, Hirsch J, Murphy E, Leibel RL. Effects of changes in body weight on carbohydrate metabolism, catecholamine excretion and thyroid function. Am J Clin Nutr 2000;71:1421-1432.

14. Rotondi M, Leporati P, La Manna A, Pirali B, Mondello T, Fonte R, Magri F, Chiovato L. Raised serum TSH levels with morbid obesity: is it enough to diagnose subclinical hypothyroidism? Eur $\mathrm{J}$ Endocrinol 2009;160:403-408. Epub 2008 Dec 10

15. Knudsen N, Laurberg P, Rasmussen LB, Bülow I, Perrild H, Ovesen $L$, Jørgensen $T$. Small differences in thyroid function may be important for body mass index and the occurrence of obesity in the population. J Clin Endocrinol Metab 2005;90:4019-4024. Epub 2005 May 3
16. Reinehr T, de Sousa G, Andler W. Hyperthyrotropinemia in obese children is reversible after weight loss and is not related to lipids. J Clin Endocrinol Metab 2006;91:3088-3091. Epub 2006 May 9

17. Marras V, Casini M.R, Pilia S, Carta D, Civolani P, Porcu M, Uccheddu AP, Loche S. Thyroid function in obese children and adolescents. Horm Res Paediatr 2010;73:193-197. Epub 2010 Mar 3

18. Biondi B. Thyroid and obesity: an intriguing relationship. J Clin Endocrinol Metab 2010;95:3614-3617.

19. Tagliaferri M, Berselli ME, Calo G, Minocci A, Savia G, Petroni ML, Viberti GC, Liuzzi A. Subclinical hypothyroidism in obese patients: relation to resting energy expenditure, serum leptin, body composition, and lipid profile. Obes Res 2001;9:196-201.

20. Chomard P, Vernhes G, Autissier N, Debry G. Serum concentrations of total T4, T3, reverse T3 and free T4, T3 in moderately obese patients. Hum Nutr Clin Nutr 1985;39:371-378.

21. Matzen LE, Kvetny J, Pedersen KK. TSH, thyroid hormones and nuclear-binding of T3 in mononuclear blood cells from obese and non-obese women. Scand J Clin Lab Invest 1989;49:249-253.

22. Duntas $L$, Hauner $H$, Rosenthal J, Pfeiffer EF. Thyrotropin releasing hormone (TRH) immunoreactivity and thyroid function in obesity. Int J Obes 1991;15:83-87.

23. Naslund E, Andersson I, Degerblad M, Kogner P, Kral JG, Rossner S, Hellström PM. Associations of leptin, insulin resistance and thyroid function with long-term weight loss in dieting obese men. $\mathrm{J}$ Intern Med 2000;248:299-308.

24. lacobellis G, Ribaudo MC, Zappaterreno A, lannucci CV, Leonetti F. Relationship of thyroid function with body mass index, leptin, insulin sensitivity and adiponectin in euthyroid obese women. Clin Endocrinol (Oxf) 2005;62:487-491.

25. Aeberli I, Jung A, Murer SB, Wildhaber J, Wildhaber-Brooks J, Knöpfli BH, Zimmermann MB. During rapid weight loss in obese children, reductions in TSH predict improvements in insulin sensitivity independent of changes in body weight or fat. J Clin Endocrinol Metab 2010;95:5412-5418. Epub 2010 Sep 15

26. Reinehr T. Obesity and thyroid function. Mol Cell Endocrinol 2010;316:165-171. Epub 2009 Jun 18

27. De Pergola G, Ciampolillo A, Paolotti S, Trerotoli P, Giorgino R. Free Triiodothyronine and thyroid stimulating hormone are directly associated with waist circumference, independent of insulin resistance, metabolic parameters and blood pressure in overweight and obese women. Clin Endocrinol (Oxf) 2007;67:265269. Epub 2007 Jun 4

28. Reinehr T, Isa A, de Sousa G, Dieffenbach R, Andler W. Thyroid hormones and their relation to weight status. Horm Res 2008;70:51-57. Epub 2008 May 21

29. Feldt-Rasmussen U. Thyroid and leptin. Thyroid 2007;17:413-419.

30. Zimmermann-Belsing T, Brabant G, Holst JJ, Feldt-Rasmussen U. Circulation leptin and thyroid dysfunction. Eur J Endocrinol 2003;149:257-271.

31. Nannipieri $M$, Cecchetti $F$, Anselmino $M$, Camastra $S$, Niccolini $P$, Lamacchia M, Rossi M, lervasi G, Ferrannini E. Expression of thyrotropin and thyroid hormone receptors in adipose tissue of patient with morbid obesity and/or type 2 diabetes: effects of weight loss. Int J Obes (Lond) 2009;33:1001-1006. Epub 2009 Jul 28

32. Myers MG Jr, Leibel RL, Seeley RJ, Schwartz MW. Obesity and leptin resistance: distinguishing cause from effect. Trends Endocrinol Metab 2010;21:643-651. Epub 2010 Sep 16

33. Bell A, Gagnon A, Grunder L, Parikh SJ, Smith TJ, Sorisky A. Functional TSH receptor in human abdominal preadipocytes and orbital fibroblasts. Am J Physiol Cell Physiol 2000;279:335-340.

34. Menendez C, Baldelli R, Camiña JP, Escudero B, Peino R, Dieguez C, Casanueva FF. TSH stimulates leptin secretion by a direct effect on adipocytes. J Endocrinol 2003;176:7-12. 
Longhi S et al.

Thyroid and Obesity

35. Burman KD, Latham KR, Djuh YY, Smallridge RC, Tseng YC, Lukes YG, Maunder R, Wartofsky L. Solubilized nuclear thyroid hormone receptors in circulating human mononuclear cells. J Clin Endocrinol Metab 1980;51:106-116.

36. Chrousos GP. The hypothalamic-pituitary-adrenal axis and immunemediated inflammation. N Engl J Med 1995;332:1351-1362.

37. Aijan RA, Watson PF, Findlay C, Metcalfe RA, Crisp M, Ludgate $M$, Weetman AP. The sodium iodide symporter gene and its regulation by cytokines found in autoimmunity. J Endocrinol 1998;158:351-358.

38. Pekary AE, Hershman JM. Tumor necrosis factor, ceramide, transforming growth factor-beta1, and aging reduce $\mathrm{Na}+/ /-$ symporter messenger ribonucleic acid levels in FRTL-5 cells. Endocrinolology 1998;139:703-712.

39. Pekary AE, Levin SR, Johnson DG, Berg L, Hershman JM. Tumor necrosis factor-alfa (TNF-alfa) and transforming growth factorbeta1 (TGF-beta1) inhibit the expression and activity of $\mathrm{Na}^{+} / \mathrm{K}+$ ATPase in FRTL-5 rat thyroid cells. J Interferon Cytokine Res 1997:17:185-195.

40. Kiortsis DN, Durack I, Turpin G. Effects of a low-calorie diet on resting metabolic rate and serum triiodothyronine levels in obese children. Eur J Pediatr 1999;158:446-450
41. Radetti G, Longhi S, Baiocchi M, Cassar W, Buzi F. Changes in lifestyle improve body composition, thyroid function and structure in obese children. J Endocrinol Invest 2012;35:281-285. Epub 2011 May 27

42. Bizhanova A, Kopp P. The sodium-iodide symporter NIS and pedrin in iodide homeostasis of the thyroid. Endocrinol 2009;150:10841090. Epub 2009 Feb 5

43. Radetti G, Kleon W, Buzi F, Crivellaro C, Pappalardo L, di lorgi N, Maghnie M. Thyroid function and structure are affected in childhood obesity. J Clin Endocrinol Metab 2008;93:4749-4754. Epub 2008 Oct 7

44. Rotondi M, Cappelli C, Leporati P, Chytiris S, Zerbini F, Fonte R, Magri F, Castellano M, Chiovato L. A hypoechoic pattern of the thyroid at ultrasound does not indicate autoimmune thyroid diseases in patients with morbid obesity. Eur $\mathrm{J}$ Endocrinol 2010;163:105-109. Epub 2010 May 7

45. Kershaw EE, Flier JS. Adipose tissue as an endocrine organ. J Clin Endocrinol Metab 2004;89:2548-2556.

46. Cambuli VM, Musiu MC, Incani M, Paderi M, Serpe R, Marras V, Cossu E, Cavallo MG, Mariotti S, Loche S, Baroni MG. Assessment of adiponectin and leptin as biomarkers of positive metabolic outcomes after lifestyle intervention in overweight and obese children. J Clin Endocrinol Metab 2008;93:3051-3057. Epub 2008 May 20 